\title{
PROSEDUR PERHITUNGAN DAN PELAPORAN PAJAK PENGHASILAN \\ PASAL 21 ATAS GAJI PEGAWAI PEMERINTAH \\ KABUPATEN MINAHASA SELATAN
}

\author{
Andre Mandak \\ Jenny Morasa
}

\author{
Fakultas Ekonomi dan Bisnis Magister Akuntansi \\ Universitas Sam Ratulangi Manado \\ email: andre_mandak@yahoo.com
}

\begin{abstract}
Income tax (VAT) of article 21 is a tax on income in the form of salaries, wages, fees, allowances, and other similar remuneration derived by any individual taxpayer in respect of employment or office, services, and activities. The purpose of this study is to provide an explanation of the implementation of the calculation and deduction, income tax reporting section 21 and the amount of income tax revenue has been recapitulated by the Government of South Minahasa District. This study used a descriptive analysis method by comparing theory and rules perpajakn there with the data obtained. From the research, it was found the procedure of calculation and reporting of income tax article 21 in the South Minahasa District Government has been good. It can be seen from the calculation until the reporting mechanism has been carried out based on the rules that apply. The use of services and applications for the calculation of Income Tax Article 21 of the PT. TASPEN in connection with the cooperation with the Government of South Minahasa.
\end{abstract}

Keywords: Income tax (VAT) of article 21

\section{PENDAHULUAN}

\subsection{Latar Belakang}

Meningkatkan kesejahtraan rakyat merupakan tujuan utama dari pembangunan suatu daerah. Sumber dana yang mendukung merupakan salah satu masalah dalam pembiayaan suatu pembangunan. Pembangunan akan berjalan seiring dengan adanya sumber dana yang mendukung. Dalam anggaran pendapatan dan belanja negara sumber pendapatan terbanyak didapat dari sektor perpajakan meskipun terdapat banyak sektor lain seperti sektor minyak dan gas bumi, serta bantuan luar negeri.

Ekstensifikasi perpajakan dilaksanakan dengan cara meningkatkan jumlah pajak dan objek pajak baru sedangkan intensifikasi perpajakan dilaksanakan dengan berorientasi pada peningkatan kepatuhan dan kesadaran wajib pajak, seperti dengan cara penyuluhan langsung kepada masyarakat. Dengan banyaknya perusahaan baru dan ataupun perusahaan yang sudah lama serta instansi-instansi pemerintah diharapkan meningkatkan pemasukan dari pajak penghasilan yang digunakan untuk pembiayaan negara dan pembangunan nasional nantinya.

Dari segi ekonomi, pajak merupakan perpindahan sumber daya dari sektor privat ke sektor publik. Withholding system adalah sistem pemungutan pajak yang memberi wewenang kepada pihak ketiga untuk memotong atau memungut besarnya pajak yang terutang oleh wajib pajak. Ciri-ciri sistem ini adalah wewenang untuk menentukan besarnya pajak terutang ada pada pihak ketiga, pihak selain pemerintah (fiskus) dan wajib pajak. Potongan pajak penghasilan pasal 21 dilakukan terhadap orang pribadi wajib pajak dalam negeri. Pemotongan pajak dilakukan oleh pemberi penghasilan dan dalam melaksanakan penghitungan haruslah mengikuti undang-undang perpajakan dan segala peraturan pemerintah yang berlaku guna menjadi pedoman dalam melaksanan penghitungan pajak.

Kabupaten Minahasa Selatan merupakan Kabupaten pemekaran baru di Provinsi Sulawesi Utara. Pada awalnya Pemerintah Kabupaten Minahasa Selatan hanya menggunakan SIMDA dalam proses penggajian dan perhitungan pajak penghasilan pasal 21. Pada saat ini dengan adanya kerjasama antara 
PT. Taspen dan Pemerintah Kabupaten Minahasa Selatan perhitungan dan pemotongan pajak penghasilan pasal 21 telah menggunakan layanan aplikasi yang disediakan oleh PT. Taspen.

Berdasarkan uraian tersebut, penulis tertarik untuk menulis mengenai bagaimana suatu instansi pemerintah dalam menentukan besarnya pajak penghasilan pegawai dan pelaporan serta penyetorannya oleh pemerintah dengan judul "analisis prosedur perhitungan dan pelaporan pajak penghasilan $(\mathrm{PPh})$ pasal 21 atas gaji pegawai pada pemerintah kabupaten minahasa selatan”.

\subsection{Tujuan Penelitian}

Penelitian ini dilakukan dengan tujuan untuk memberikan penjelasan tentang pelaksanaan penghitungan dan pemotongan, mengevaluasi prosedur pelaporan besarnya pemotongan pajak penghasilan pasal 21 atas gaji pegawai Pemerintah Kabupaten Minahasa Selatan.

\section{TINJAUAN PUSTAKA}

\subsection{Pengertian Pajak}

Erly Suandy (2011:5) pajak merupakan pungutan berdasarkan undang-undang oleh pemerintah, yang sebagian dipakai untuk penyediaan barang dan jasa publik". Sedangkan menurut Waluyo (2013:2), pajak adalah iuran kepada negara (yang dapat dipaksakan) yang terutang oleh yang wajib membayarnya menurut peraturan-peraturan, dengan tidak mendapat perestasi kembali, yang langsung dapat ditunjuk, dan yang gunanya adalah untuk membiayai pengeluaran-pengeluaran umum berhubung dengan tugas negara yang menyelenggarakan pemerintahan.

\subsection{Fungsi Pajak}

Waluyo (2013:6), ada dua fungsi pajak yaitu sebagai berikut.

1. Fungsi Penerimaan (budgeter)

Pajak berfungsi sebagai sumber dana yang diperuntukkan bagi pembiayaan pengeluaranpengeluaran pemerintah. Sebagai contoh: diamsukannya pajak dalam APBN sebagai penerimaan dalam negeri.

2. Fungsi Mengatur (Reguler)

Pajak berfungsi sebagai alat untuk mengatur atau melaksanakan kebijakan di bidang sosial dan ekonomi. Sebagai contoh: dikenakannya pajak yang lebih tinggi terhadap minuman keras, dapat ditekan. Demikian pula terhadap barang mewah.

\subsection{Cara Pemungutan Pajak}

Cara pemungutan pajak menurut Waluyo (2013:16-17) adalah sebagai berikut.

1. Stelsel pajak, cara pemungutan pajak dilakukan berdasarkan 3 (tiga) stelsel, adalah sebagai berikut.

a. Stelsel nyata (rill stelsel)

Pengenaan pajak didasarkan pada objek (penghasilan) yang nyata, sehingga pemungutannya baru dapat dilakukan pada akhir tahun pajak, yakni setelah penghasilan yang sesungguhnya telah dapat diketahui. Kelebihan stelsel ini adalah pajak yang dikenakan lebih realistis. Kelemahannya adalah pajak baru dapat dikenakan pada akhir periode (setelah penghasilan rill diketahui)

b. Stelsel anggapan (fictive stelsel)

Pengenaan pajak didasarkan pada suatu anggapan yang diatur oleh undang-undang, sebagai contoh penghasilan satu tahun dianggap sama dengan tahun sebelumnya sehingga pada awal tahun pajak telah dapat ditetapkan besarnya pajak yang terutang untuk tahun pajak berjalan. Kelebihan stelsel ini adalah yang dibayar selama tahun berjalan, tanpa harus menunggu akhir tahun. Kelemahannya adalah pajak yang dibayarkan tidak berdasarkan pada keadaan yang sesungguhnya.

c. Stelsel campuran 
Stelsel ini merupakan kombinasi antara stelsel nyata dan stelsel anggapan. Pada awal tahun, besarnya pajak dihitung berdasarkan suatu anggapan, kemudian pada akhir tahun besarnya pajak disesuaikan dengan keadaan yang sebenarnya. Apabila besarnya pajak menurut kenyataan lebih besar dari pada pajak menurut anggapan, maka wajib pajak harus menambah kekurangannya. Demikian pula sebaliknya, apabila lebih kecil, maka kelebihannya dapat diminta kembali.

2. Sistem pemungutan pajak, sistem ini dapat dibagi menjadi berikut ini.

a. Sistem official assessment

Sistem ini merupakan sistem pemungutan pajak yang memberi wewenang kepada pemerintah (fiskus) untuk menentukan besarnya pajak yang terutang. Ciri-ciri official assessment adalah sebagai berikut.

1) Wewenang untuk menetukan besarnya pajak terutang berada pada fiskus

2) Wajib pajak bersifat pasif

3) Utang pajak timbul setelah dikeluarkan surat ketetapan pajak oleh fiskus.

b. Sistem self assessment

Sistem ini merupakan pemungutan pajak yang memberi wewenang, kepercayaan, tanggungjawab kepada wajib pajak untuk menghitung, memperhitungkan, membayar, dan melaporkan sendiri besarnya pajak yang harus dibayar.

c. Sistem withholding

Sistem ini merupakan sistem pemungutan pajak yang memberi wewenang kepada pihak ketiga untuk memotong atau memungut besarnya pajak yang terutang oleh wajib pajak.

\subsection{Pajak Penghasilan}

Pajak Penghasilan $(\mathrm{PPh})$ adalah pajak yang dikenakan kepada orang pribadi atau badan atas penghasilan yang diterima atau diperoleh dalam satu tahun pajak. Siti Resmi (2011:74), pajak penghasilan adalah pajak yang dikenakan terhadap subjek pajak atas penghasilan yang diterima atau yang diperolehnya. Pajak penghasilan (PPh) pasal 21 adalah pajak atas penghasilan berupa gaji, upah, honorarium, tunjangan, dan pembayaran lain dengan nama apapun yang diterima atau diperoleh wajib pajak orang pribadi dalam negeri sehubungan dengan pekerjaan atau jabatan, jasa, dan kegiatan.

\subsection{Wajib Pajak dan Tidak Termasuk Wajib Pajak PPh Pasal 21}

1. Wajib Pajak PPh Pasal 21

Siti Resmi (2011:168-169), penerima penghasilan yang dipotong PPh pasal 21 dan/atau PPh pasal 26 adalah orang pribadi yang merupakan sebagai berikut.

1) Pegawai.

2) Penerima uang pesangon, pensiun atau uang manfaat pensiun, tunjangan hari tua atau jaminan hari tua, termasuk ahli warisnya.

3) Bukan pegawai yang menerima atau memperoleh penghasilan sehubungan dengan pekerjaan, jasa, atau kegiatan, antara lain sebagai berikut.

a. Tenaga ahli yang melakukan pekerjaan bebas, yang terdiri dari pengacara, akuntan, arsitek, dokter, konsultan, notaris, penilai, dan aktuaris.

b. Pemain musik, pembawa acara, penyanyi, pelawak, bintang film, bintang sinetron, bintang iklan, sutradara, kru film, foto model, peragawan/peragawati, pemain drama, penari, pemahat, pelukis, dan seniman lainnya.

c. Olahragawan.

d. Penasihat, pengajar, pelatih, penceramah, penyuluh, dan moderator.

e. Pengarang, peneliti, dan penerjemah.

f. Pemberi jasa dalam segala bidang termasuk teknik komputer dan sitem aplikasinya, telekomunikasi, elektronika, fotografi, ekonomi, dan sosial serta pemberi jasa kepada suatu kepanitiaan. 
g. Agen iklan.

h. Pengawas atau pengelolah proyek.

i. Pembawa pesanan atau yang menemukan langganan atau yang menjadi perantara.

j. Petugas penjaja barang dagangan.

k. Petugas dinas luar asuransi.

1. Distributor perusahaan multilevel marketing atau direct selling dan kegiatan sejenis lainnya.

4) Peserta kegiatan yang menerima atau memperoleh penghasilan sehubungan dengan keikutsertaannya dalam suatu kegiatan, antara lain sebagai berikut.

a. Peserta perlombaan dalam segala bidang, antara lain perlombaan olahraga, seni, ketangkasan, ilmu pengetahuan, teknologi, dan perlombaan lainnya.

b. Peserta rapat, konferensi, sidang, pertemuan, atau kunjungan kerja.

c. Peserta atau anggota dalam suatu kepanitiaan sebagai penyelenggara kegiatan tertentu.

d. Peserta pendidikan, pelatihan, dan magang.

e. Peserta kegiatan lainnya.

2. Tidak Termasuk Wajib Pajak PPh Pasal 21

Siti Resmi (2011:169), tidak termasuk dalam pengertian Penerima Penghasilan yang dipotong $\mathrm{PPh}$ pasal 21 adalah sebagai berikut.

1) Pejabat perwakilan diplomatik dan konsulat atau pejabat lain dari negara asing, dan orang-orang yang diperbantukan kepada mereka yang bekerja pada dan bertempat tinggal bersama mereka, dengan syarat bukan warga negara Indonesia dan di Indonesia tidak menerima atau memperoleh penghasilan lain di luar jabatan atau pekerjaannya tersebut, serta negara yang bersangkutan memberikan perlakuan timbal balik.

2) Pejabat perwakilan organisasi internasional sebagaimana dimaksud dalam pasal 3 ayat (1) huruf c undang-undang pajak penghasilan, yang telah ditetapkan oleh Menteri keuangan, dengan syarat bukan warga negara Indonesia dan tidak menjalankan usaha atau kegiatan atau pekerjaan lain untuk memperoleh penghasilan dari Indonesia.

\subsection{Subjek Pajak Penghasilan Pasal 21}

Berdasarkan pasal 2 ayat 1 UU No. 36 Tahun 2008, subjek pajak dikelompokan sebagai berikut.

1. Subjek pajak orang pribadi

Orang pribadi sebagai subjek pajak dapat bertempat tinggal di Indonesia ataupun di Luar Indonesia.

2. Subjek pajak warisan yang belum terbagi sebagai satu kesatuan, menggantikan yang berhak.

Warisan yang belum terbagi sebagai satu kesatuan merupapakan subjek pajak pengganti, menggantikan mereka yang berhak yaitu ahli waris. Penunjukan warisan yang belum terbagi sebagai subjek pajak pengganti dimaksudkan agar pengenaan pajak atas penghasilan yang berasal dari warisan tersebut tetap dapat dilaksanakan.

3. Subjek pajak badan

Badan adalah sekumpulan orang dan/atau modal yang merupakan kesatuan baik yang melakukan usaha maupun yang tidak melakukan usaha yang meliputi perseroan terbatas, perseroan komanditer, perseroan lainnya, badan usaha milik negara atau badan usaha milik daerah dengan nama dan dalam bentuk apapun, firma, kongsi, koprasi, dana pensiun, persekutuan, perkumpulan, yayasan, organisasi massa, organisasi sosial politik, atau organisasi lainnya, lembaga, dan bentuk badan lainnya termasuk kontrak investasi kolektif 
dan bentuk usaha tetap. Badan usaha milik negara dan badan usaha milik daerah merupakan subjek pajak tanpa memperhatikan nama dan bentuknya sehingga setiap unit tertentu dari pemerintah, misalnya lembaga badan, dan sebagainya yang dimiliki oleh pemerintah pusat dan pemerintah daerah yang menjalankan usaha atau melakukan kegiatan untuk memperoleh penghasilan merupakan subjek pajak. Dalam pengertian perkumpulan termasuk juga asosiasi, persatuan, perhimpunan, atau ikatan dari pihak-pihak yang mempunyai kepentingan yang sama.

4. Subjek pajak bentuk usaha tetap (BUT)

Bentuk usaha tetap adalah bentuk usaha yang dipergunakan oleh orang pribadi yang tidak bertempat tinggal di Indonesia, orang pribadi yang berada di Indonesia tidak lebih dari 183 (seratus delapan puluh tiga) hari dalam jangka waktu 12 (dua belas) bulan, dan badan yang tidak didirikan dan tidak bertempat kedudukan di Indonesia, yang dapat berupa.

1) Tempat kedudukan manajemen

2) Cabang perusahaan

3) Kantor perwakilan

4) Gedung kantor

5) Pabrik

6) Bengkel

7) Gudang

8) Ruang untuk promosi dan penjualan

9) Pertambangan dan penggalian sumber alam

10) Wilayah kerja pertambangan minyak dan gas bumi

11) Perikanan, peternakan, pertanian, perkebunan, atau kehutanan

12) Proyek konstruksi, instalasi, atau proyek perakitan

13) Pemberian jasa dalam bentuk apapun oleh pegawai atau orang lain, sepanjang dilakukan lebih dari 60 (enam puluh) hari dalam jangka waktu 12 (dua belas) bulan

14) Orang atau badan yang bertindak selaku agen yang kedudukannya tidak bebas

15) Agen atau pegawai dari perusahaan asuransi yang tidak didirikan dan tidak bertempat kedudukan di Indonesia yang menerima premi asuransi atau menanggung resiko di Indonesia

16) Komputer, agen elektronik, peralatan otomatis yang dimiliki, disewa, atau digunakan oleh penyelenggara transaksi elektronik untuk menjalankan kegiatan usaha melalui internet.

\subsection{Tidak Termasuk Subjek Pajak Penghasilan Pasal 21}

Adapun penerima penghasilan yang tidak dipotong pajak penghasilan pasal 21, yaitu sebagai berikut.

1. Pejabat perwakilan diplomatik dan konsulat atau pejabat lain dari negara asing, dan orangorang yang diperbantukan kepada mereka yang bekerja pada dan bertempat tinggal bersama mereka, yaitu dengan syarat sebagai berikut.

1) bukan Warga Negara Indonesia

2) di Indonesia tidak menerima atau memperoleh penghasilan lain di luar jabatan atau pekerjaannya tersebut serta negara yang bersangkutan memberikan perlakuan timbal balik;

2. Pejabat perwakilan organisasi internasional yang ditetapkan oleh Keputusan Menteri Keuangan sepanjang bukan Warga Negara Indonesia dan tidak menjalankan usaha atau kegiatan atau pekerjaan lain untuk memperoleh penghasilan di Indonesia.

\subsection{Objek dan Bukan Objek Pajak Penghasilan Pasal 21}

Siti Resmi (2011:171), penghasilan yang dipotong PPh pasal 21 adalah sebagai berikut. 
1. Penghasilan yang diterima atau diperoleh pegawai tetap, baik berupa penghasilan yang bersifat teratur maupun tidak teratur.

2. Penghasilan yang diterima atau diperoleh penerima pensiun secara teratur berupa uang pensiun atau penghasilan sejenisnya.

3. Penghasilan sehubungan denganpemutusan hubungan kerja dan penghasilan sehubungan dengan pensiun yang diterima secara skaligus berupa uang pesangon, uang manfaat pensiun, uang tunjangan hari tua atau jaminan hari tua, dan pembayaran lain sejenis.

4. Penghasilan pegawai tidak tetap atau tenaga kerja lepas, berupa upah harian, upah mingguan, upah satuan, upah borongan, atau upah yang dibayarkan secara bulanan.

5. Imbalan kepada bukan pegawai, antara lain berupa honorarium, komisi, fee, dan imbalan sehubungan dengan pekerjaan, jasa, dan kegiatan yang dilakukan.

6. Imbalan kepada peserta kegiatan, antara lain berupa uang saku, uang representasi, uang rapat, honorarium, hadiah atau penghargaan dengan nama

Adapun pengahsilan yang tidak dipotong pajak penghasilan pasal 21, yaitu sebagai berikut.

1. Pembayaran manfaat atau santunan asuransi dari perusahaan asuransi kesehatan,asuransi kecelakaan, asuransi jiwa, asuransi dwiguna, dan asuransi bea siswa.

2. Penerimaan dalam bentuk natura dan/atau kenikmatan dalam bentuk apapun yang diberikan oleh Wajib Pajak atau Pemerintah, kecuali diberikan oleh bukan Wajib Pajak, Wajib Pajak yang dikenakan Pajak Penghasilan yang bersifat final dan yang dikenakan Pajak Penghasilan berdasarkan norma penghitungan khusus (deemed profit)

3. Iuran pensiun yang dibayarkan kepada dana pensiun yang pendiriannya telah disahkan oleh Menteri Keuangan dan iuran tunjangan hari tua atau iuran jaminan hari tua kepada badan penyelenggara tunjangan hari tua atau badan penyelenggara jaminan sosial tenaga kerja yang dibayar oleh pemberi kerja

4. Zakat yang diterima oleh orang pribadi yang berhak dari badan atau lembaga amil zakat yang dibentuk atau disahkan oleh Pemerintah

5. Beasiswa yang diterima atau diperoleh Warga Negara Indonesia dari Wajib Pajak pemberi beasiswa dalam rangka mengikuti pendidikan formal/nonformal yang terstruktur baik di dalam negeri maupun luar negeri.

\subsection{Pemotong Pajak Penghasilan Pasal 21}

Dalam UU No. 36 tahun 2008 tentang pajak penghasilan pasal 21 ayat 1 yaitu, Pemotongan pajak atas penghasilan sehubungan dengan pekerjaan, jasa, atau kegiatan dengan nama dan dalam bentuk apa pun yang diterima atau diperoleh Wajib Pajak orang pribadi dalam negeri wajib dilakukan oleh sebagai berikut.

1. Pemberi kerja yang membayar gaji, upah, honorarium, tunjangan, dan pembayaran lain sebagai imbalan sehubungan dengan pekerjaan yangdilakukan oleh pegawai atau bukan pegawai

2. Bendahara pemerintah yang membayar gaji, upah, honorarium, tunjangan, dan pembayaran lain sehubungan dengan pekerjaan, jasa, atau kegiatan

3. Dana pensiun atau badan lain yang membayarkan uang pensiun dan pembayaran lain dengan nama apa pun dalam rangka pensiun

4. Badan yang membayar honorarium atau pembayaran lain sebagai imbalan sehubungan dengan jasa termasuk jasa tenaga ahli yang melakukan pekerjaan bebas

5. Penyelenggara kegiatan yang melakukan pembayaran sehubungan dengan pelaksanaan suatu kegiatan.

Dasar hukum bendahara sebagai pemotong pajak penghasilan (PPh) pasal 21 sebagai berikut.

1. Undang-Undang Nomor 6 tahun 1983 tentang ketentuan umum dan tata cara perpajakan sebagaimana telah diubah terakhir dengan UU Nomor 16 tahun 2009.

2. Undang-Undang Nomor 7 tahun 1983 tentang pajak penghasilan sebagaimana telah diubah terakhir dengan Undang-Undang Nomor 36 tahun 2008. 
3. Peraturan Pemerintah Republik Indonesia Nomor 45 tahun 1994 tentang pajak penghasilan bagi pejabat Negara, pegawai negeri sipil, anggota ABRI dan para pensiunan atas penghasilan yang dibebankan kepada keuangan Negara atau keuangan daerah.

4. Peraturan Pemerintah Nomor 149 tahun 2000 tentang pemotongan PPh pasal 21 atas penghasilan berupa uang pesangon, uang tebusan, dan tunjangan hari tua.

5. Peraturan Menteri Keuangan nomor : 181/PMK.03/2007 tentang bentuk isi surat pemberitahuan, serta tata cara pengambilan, pengisian, penandatanganan, dan penyampaian surat pemberitahuan.

6. Peraturan Menteri Keuangan nomor : 184/PMK.03/2007 tentang penentuan tanggal jatuh tempo pembayaran dan penyetoran pajak, penentuan tempat pembayaran pajak, dan tata cara pembayaran, penyetoran, pelaporan pajak, serta tata cara pengansuran dan penundaan pembayaran pajak.

7. Peratuaran Menteri Keuangan nomor : 186/PMK.03/2007 tentang wajib pajak tertentu yang dikecualikan dari pengenaan sanksi administrasi berupa denda karena tidak menyampaikan surat pemberitahuan dalam jangka waktu yang ditentukan.

8. Peraturan Menteri Keuangan nomor : 190/PMK.03/2007 tentang tata cara pengambilan pembayaran pajak yang seharusnya tidak terutang.

9. Peraturan Menteri Keuangan nomor : 246/PMK.03/2008 tentang bea siswa yang dikecualikan dari objek pajak penghasilan.

10. Peraturan Menteri Keuangan nomor : 250/PMK.03/2008 tentang besarnya biaya jabatan atau biaya pensiun yang dapat dikurangkan dari penghasilan bruto pegawai tetap atau pensiunan.

11. Peraturan Menteri Keuangan nomor : 252/PMK.03/2008 tentang petunjuk pelaksanaan pemotongan pajak atas penghasilan sehubungan dengan pekerjaan, jasa dan kegiatan orang pribadi.

12. Peraturan Menteri Keuangan nomor : 254/PMK.03/2008 tentang penetapan bagian penghasilan sehubungan dengan pekerjaan dari pegawai harian dan mingguan serta pegawai tidak tetap lainnya yang tidak dikenakan pemotongan pajak penghasilan.

13. Peraturan Direktur Jendral Pajak No. PER-57/PJ/2009 tanggal 25 mei 2009 tentang pedoman teknis dan tata cara pemotongan, penyetoran dan pelaporan pajak penghasilan pasal 21 atau pajak penghasilan pasal 26 sehubungan dengan jasa dan kegiatan orang pribadi.

14. Peraturan Direktur Jendral Pajak No. PER-32/PJ/2009 tanggal 25 mei 2009 tentang bentuk formulir surat pemberitahuan masa pajak penghasilan pasal 21 dan/atau pasal 26 dan bukti pemotongan atau pemungutan pajak penghasilan pasal 21 dan/atau pasal 26.

15. Peraturan Direktur Jendral Pajak No. PER-38/PJ/2009 tanggal 23 juni 2009 tentang bentuk formulir surat setoran pajak.

\subsection{Tatacara Perhitungan Pajak Penghasilan Pasal 21}

Mulai bulan Januari 2013, Penghasilan Tidak Kena Pajak (PTKP) telah berubah. Sekarang untuk Wajib Pajak yang berstatus tidak kawin dan tidak mempunyai tanggungan jumlah PTKP-nya sebesar Rp 24.300.000,00 atau setara dengan Rp 2.025.000,00 per bulan. Dengan adanya perubahan itu, tatacara penghitungan PPh Pasal 21 juga mengalami perubahan. Perubahan itu diatur dalam Peraturan Direktur Jenderal Pajak Nomor Per-31/PJ/2012 tentang Pedoman Teknis Tata Cara Pemotongan, Penyetoran dan Pelaporan Pajak Penghasilan Pasal 21 dan/atau Pajak Penghasilan Pasal 26 Sehubungan dengan Pekerjaan, Jasa, dan Kegiatan Orang Pribadi.

Penghitungan PPh Pasal 21 menurut aturan yang baru tersebut, dibedakan menjadi 6 macam, yaitu PPh Pasal 21 untuk Pegawai tetap dan penerima pensiun berkala, PPh pasal 21 untuk pegawai tidak tetap atau tenaga kerja lepas, PPh pasal 21 bagi anggota dewan pengawas atau dewan komisaris yang tidak merangkap sebagai pegawai tetap, penerima imbalan lain yang bersifat tidak teratur, dan peserta program pensiun yang masih berstatus sebagai pegawai yang menarik dana 
pensiun. Di kesempatan ini akan dipaparkan tentang contoh perhitungan PPh pasal 21 untuk Pegawai Tetap dan Penerima Pensiun Berkala.

Penghitungan PPh Pasal 21 untuk pegawai tetap dan penerima pensiun berkala dibedakan menjadi 2 (dua), yaitu sebagai berikut.

1. Penghitungan PPh Pasal 21 masa atau bulanan yang rutin dilakukan setiap bulan.

2. Penghitungan kembali yang dilakukan setiap masa pajak Desember (atau masa pajak dimana pegawai berhenti bekerja).

\subsection{Sanksi Administrasi}

Dalam melaksanakan pemenuhan kewajiban perpajakan, wajib pajak seringkali dikenakan sanksi pajak yang bersifat administrasi maupun pidana. Ilyas dan Burton (2013:66-72) mengemukakan sanksi administrasi terdiri dari tiga macam, yaitu sebagai berikut.

1. Sanksi administrasi berupa denda

Sanksi administrasi berupa denda tergolong sanksi yang masih dapat dipenuhi pelaksanaannya karena hanya mengenakan sanksi sejumlah uang kepada wajib pajak yang tidak patuh dalam melaksanakan administrasi perpajakan.

2. Sanksi administrasi berupa bunga

Sanksi administrasi berupa bunga tergolong sebagai sanksi yang lebih berat dibandingkan dengan sanksi denda, sanksi bunga diatur dalam berbagai terkait dengan persoalan kesalahan yang dilakukan wajib pajak.

3. Sanksi admistrasi berupa kenaikan

Sanksi administrasi berupa kenaikan merupakan sanksi administrasi dengan memberikan sejumlah kenaikan pada besaran pajak yang harus dibayar. Jika dihitung sacara nominal, sanksi kenaikan merupakan sanksi administrasi yang paling berat dibandingkan dengan sanksi denda maupun sanksi bunga.

\section{METODE PENELITIAN}

\subsection{Jenis Data dan Sumber Data}

Jenis data yang digunakan dalam penelitian ini adalah data kualitatif yaitu penggambaran tentang objek penelitian dan kuantitatif yaitu berupa daftar pegawai, daftar mutasi gaji pegawai, perhitungan pajak penghasilan pasal 21 pada pegawai menurut pemerintah kabupaten Minahasa Selatan, dan rekapitulasi pemotongan pajak penghasilan pasal 21 oleh pemerintah kabupaten Minahasa Selatan.

\subsection{Metode Pengumpulan Data}

Informasi dalam penelitian ini didapatkan melalui suatu proses pengumpulan data. Proses atau teknik pengumpulan data tersebut adalah penelitian lapangan (field research) atau mencari dan mengumpulkan data langsung dari objek penelitian dengan cara wawancara, dokumentasi, dan observasi.

\subsection{Metode Analisis Data}

Metode analisis yang digunakan adalah analisis deskriptif yaitu analisis dilakukan dengan cara membandingkan antara teori-teori yang telah ada dengan data-data yang didapat dari studi kasus.

\subsection{Definisi Oprasional}

Dalam judul laporan akhir ini Analisis Prosedur Perhitungan dan Pelaporan Pajak Penghasilan (PPh) Pasal 21 Atas Gaji Pegawai pada Pemerintah Kabupaten Minahasa Selatan. Agar supaya tidak terjadi kesalahan dalam menginteprestasikan judul, maka sangat diperlukan penjelasan mengenai laporan akhir tersebut adalah sebagai berikut. 
1. Analisis prosedur perhitungan pajak penghasilan pasal 21 atas gaji pegawai adalah proses kajian yang dilaksanakan terhadap serangkaian tindakan perhitungan pajak penghasilan pasal 21 atas gaji yang diperoleh pegawai yang seharusnya dijalankan.

2. Analisis prosedur pelaporan pajak penghasilan pasal 21 atas gaji pegawai adalah adalah proses kajian yang dilaksanakan terhadap serangkaian tindakan pelaporan pajak penghasilan pasal 21 atas gaji yang diperoleh pegawai yang seharusnya dijalankan.

3. Pajak penghasilan pasal 21 adalah pajak atas penghasilan berupa gaji, upah, honorarium, tunjangan, dan pembayaran lain dengan nama apapun yang diterima atau diperoleh wajib pajak orang pribadi dalam negeri sehubungan dengan pekerjaan atau jabatan, jasa, dan kegiatan.

\section{HASIL PENELITIAN DAN PEMBAHASAN}

\subsection{Hasil Penelitian}

Setelah menjabarkan uraian teoritis prosedur perhitungan dan pelaporan pajak penghasilan pasal 21 atas gaji pegawai juga mendeskripsikan mengenai Pemerintah Kabupaten Minahasa Selatan, maka hasil penelitian sebagai berikut.

\subsubsection{Jumlah Pegawai}

Di dalam mendukung operasional organisasi, Pemerintah Kabupaten Minahasa Selatan telah memiliki pegawai negeri sipil yang menduduki berbagai posisi sesuai dengan kebutuhan operasional organsisasi. Saat ini jumlah pegawai negeri sipil yang telah ada adalah sebanyak 4.207 orang.

\subsubsection{Sistem Penggajian Pemerintah Kabupaten Minahasa Selatan}

Mekanisme penggajian pada Pemerintah Kabupaten Minahasa Selatan adalah melaui pengajuan permintaan penerbitan daftar gaji dari setiap satuan kerja perangkat daerah (SKPD) atau dari setiap kecamatan-kecamatan kepada Dinas Pengelola Keuangan, Pendapatan dan Aset Kabupaten Minahasa Selatan. Kemudian diterbitkan daftar gaji selanjutnya masing-masing satuan kerja perangkat daerah (SKPD) membuat surat perintah membayar (SPM) kepada Dinas Pengelola Keuangan, Pendapatan dan Aset Kabupaten Minahasa Selatan untuk diterbitkan surat perintah pencairan dana (SP2D) ke Bank Sulut sebagai rekening kas umum daerah (RKUD) dan kemudian disalurkan ke rekening Bank Sulut masing-masing pegawai negeri sipil.

Dalam pelaksanaan mekanisme penggajian Dinas Pengelolah Keuangan, Pendapatan dan Aset Pemerintah Kabupaten Minahasa Selatan membuka pengajuan permintaan penerbitan daftar gaji 15 (lima belas) hari sebelum penerimaan gaji. Dalam proses perhitungan penggajian, pemerintah Kabupaten Minahasa Selatan melakukan perhitungan secara sistematis dengan menggunakan layanan aplikasi perhitungan gaji pegawai negeri sipil. Layanan aplikasi perhitungan gaji pegawai negeri sipil disediakan oleh PT. Taspen sehubungan dengan adanya kerjasama antara Pemerintah Kabupaten Minhasa Selatan dan PT. Taspen. Secara rutin per triwulan data gaji pegawai tersebut diupdate ke PT. Taspen. Dari hasil penelitian jumlah pembayaran gaji pegawai sampai dengan bulan November 2014 adalah Rp 196.350.314.167.

\subsubsection{Mekanisme Perhitungan Pemotongan Pajak Penghasilan Pasal 21 Perhitungan Pemotongan PPh Pasal 21}

\begin{tabular}{|l|l|l|l|}
\hline Penerimaan & & & Rp 2.570.200 \\
\hline Gaji pokok & $10 \%$ & & $\operatorname{Rp~257.020~}$ \\
\hline Tunjangan Istri/Suami & $2 \%$ & & Rp 51.404 \\
\hline Tunjangan Anak & & & Rp 185.000 \\
\hline Tunjangan Umum & 3 Jiwa & Rp 209.280 \\
\hline Tunjangan Beras & & Rp 3.272.904 \\
\hline \multicolumn{2}{|l|}{ Gaji Kotor } & Rp 136.735 & \\
\hline Pengurangan & $4,75 \%$ & Rp 163.645 & \\
\hline Biaya 1 & $5 \%$ & & \\
\hline Biaya 2 & \multicolumn{2}{l}{} \\
\hline
\end{tabular}




\begin{tabular}{|l|l|l|l|}
\hline \multicolumn{2}{|c|}{ Total Biaya } & & Rp 300.380 \\
\hline \multicolumn{2}{|c|}{ Gaji bersih } & & Rp 2.972.524 \\
\hline Gaji bersih setahun & & & Rp 35.670.288 \\
\hline PTKP Pribadi & $\operatorname{Rp} 24.300 .000$ & & \\
\hline Kawin & $\operatorname{Rp} 2.025 .000$ & & \\
\hline Anak & $\operatorname{Rp} 2.025 .000$ & & Rp 28.350.000 \\
\hline PTKP & & & Rp 7.320.288 \\
\hline PKP & & & \\
\hline & & & Rp 366.014 \\
\hline PPh Pasal 21 atas gaji setahun & $\mathbf{5 \%}$ & Rp 30.501 \\
\hline PPh Pasal 21 atas gaji sebulan & & \\
\hline
\end{tabular}

Sumber : Bidang Perbendaharaan Dinas Pengelolah Keuangan Pendapatan dan Aset Kabupaten Minahasa Selatan

Contoh perhitungan pemotongan pajak penghasilan pasal 21 atas gaji pegawai golongan III B dan telah memiliki NPWP dengan satu orang istri dan satu orang anak. Biaya 1 (satu) merupakan iuran pensiun yang didapat dari gaji pokok ditambah tunjangan istri atau suami dan dijumlahkan dengan tunjangan anak kemudian dikalikan 4,75\%. Biaya 2 (dua) merupakan biaya jabatan yang didapat dari gaji kotor dikalikan dengan $5 \%$.

\subsubsection{Mekanisme Pemotongan, Penyetoran dan Pelaporan PPh Pasal 21}

Mekanisme pemotongan pajak penghasilan (PPh) pasal 21 oleh Pemerintah Kabupaten Minahasa Selatan dalam hal ini Dinas Pengelolah Keuangan, Pendapatan dan Aset dilakukan dengan menggunakan sistem atau layanan aplikasi dari PT. Taspen. Pemotongan dilakukan setelah terlebih dahulu melakukan penghitungan pajak penghasilan pasal 21 atas gaji pegawai. Secara otomatis langsung terpotong dalam sistem penggajian.

Penyetoran pajak penghasilan ( $\mathrm{PPh}$ ) pasal 21, dilakukan secara kolektif. Pada penyetoran pajak penghasilan dilakukan setelah gaji pegawai negeri sipil seluruh satuan kerja perangkat daerah Pemerintah Kabupaten Minahasa Selatan telah terbayarkan.

Dinas Pengelolah Keuangan, Pendapatan dan Aset merekap seluruh gaji dari setiap satuan kerja perangkat daerah yang sudah tercairkan untuk dilakukan penyetoran pajak. Penyetoran pajak dilakukan 3 (tiga) hari setelah pencairan gaji. Kemudian untuk proses penyetoran pajak penghasilan ( $\mathrm{PPh}$ ) pasal 21 disetor melalui sistem RTGS dari Bank Sulut sebagai bank daerah penyalur gaji pegawai ke bank persepsi yaitu PT. Bank Negara Indonesia (BNI) dan kemudian langsung di transfer ke Kas Negara. Apabila bendahara pemerintah terlambat menyetor dapat dikenakan sanksi administrasi. Untuk proses pelaporan pajak dibebankan kepada masing-masing satuan kerja perangkat daerah (SKPD). Dari proses penelitian, pemotongan pajak penghasilan $(\mathrm{PPh})$ pasal 21 dari Januari sampai dengan bulan November 2014 adalah sebanyak Rp 8.986.335.470.

\subsection{Pembahasan}

Analisa yang dilakukan untuk mekanisme penyetoran dan pelaporan pajak penghasilan $(\mathrm{PPh})$ pasal 21 berdasarkan hasil penelitian yang dilakukan sebagai berikut.

1. Prosedur perhitungan pajak sudah dilakukan menggunakan sistem yang akan secara otomatis terpotong. Sistem ini ada dalam layanan aplikasi perhitungan gaji pegawai negeri sipil yang disediakan oleh PT. Taspen sehubungan dengan adanya kerjasama antara Pemerintah Kabupaten Minhasa Selatan dan PT. Taspen. Secara rutin per triwulan data gaji pegawai tersebut diupdate ke PT. Taspen.

2. Proses penyetoran pajak penghasilan $(\mathrm{PPh})$ pasal 21 disetor melalui bank persepsi yaitu PT. Bank Negara Indonesi (BNI) yang kemudian langsung di transfer ke kas negara. Penyetoran pajak dilakukan 3 (tiga) hari setelah pencairan seluruh gaji pegawai negeri sipil 
Pemerintah Kabupaten Minahasa Selatan. Bendahara yang terlambat menyetor dapat dikenakan sanksi administrasi.

3. Untuk proses pelaporan pajak penghasilan $(\mathrm{PPh})$ pasal 21 di bebankan ke masing-masing SKPD untuk dilakukan pelaporan.

Berdasarkan proses pemotongan pajak penghasilan $(\mathrm{PPh})$ pasal 21 atas gaji pegawai Pemerintah Kabupaten Minahasa Selatan, telah berjalan sesuai prosedur dan peraturan-peraturan yang berlaku. Pemotongan pajak penghasilan pasal 21 yang menggunakan sistem sudah efektif dan efisien serta. Proses penghitungan dan penyetoran dilakukan setiap bulan yang kemudian di setorkan ke bank persepsi untuk di setorkan ke kas negara.

\section{PENUTUP}

\subsection{Kesimpulan}

Berdasarkan penelitian yang dilakukan pada Pemerintah Kabupaten Minahasa Selatan mengenai prosedur perhitungan dan pelaporan pajak penghasilan (PPh) pasal 21 atas gaji pegawai, maka penulis menarik kesimpulan sebagai berikut.

1. Proses perhitungan pajak penghasilan $(\mathrm{PPh})$ pasal 21 oleh Pemerintah Kabupaten Minahasa Selatan atas gaji bulanan pegawai telah dilakukan sesuai dengan ketentuan perpajakan yang berlaku. Pemerintah Kabupaten Minahasa Selatan telah melakukan kewajiban untuk menghitung dan memotong pajak penghasilan pasal 21 setiap bulan dengan baik. Dengan menggunakan sistem layanan aplikasi dari PT. Taspen sangat membantu dalam proses penghitungan dan pemotongan $\mathrm{PPh}$ pasal 21.

2. Dalam melakukan kewajiban penyetoran setiap bulannya, Pemerintah Kabupaten Minahasa Selatan menyetorkan pajak penghasilan pasal 21 yang telah dipotong dari gaji pegawai 3 (tiga) hari setelah pencairan gaji pada seluruh satuan kerja perangkat daerah Kabupaten Minahasa Selatan. Jika Pemerintah Kabupaten Minahasa Selatan tidak melakukan penyetoran setiap bulan dapat dikenakan sanksi administrasi.

3. Pemerintah Kabupaten Minahasa Selatan juga wajib melaporkan penyetoran pajak penghasilan pasal 21 yang telah dilakukan. Pelaporan pajak ini dibebanka kepada masing-masing satuan kerja perangkat daerah.

\subsection{Saran}

Prosedur perhitungan dan pelaporan pajak penghasilan pasal 21 atas gaji pegawai pada Pemerintah Kabupaten Minahasa Selatan pada dasarnya telah dilakukan dengan cukup baik. Namun dalam pelaksanan perhitungan gaji pegawai didapati beberapa beberapa kendala yang dapat berpengaruh pada waktu dalam proses perhitungan dan penyetoran pajak penghasilan pasal 21.

Oleh karena itu, penulis memberikan saran berdasarkan kesimpulan yang telah dikemukakan.

1. Dilihat dari proses penghitungan dan pemotongan pajak penghasilan pasal 21 yang menggunakan layanan aplikasi yang disediakan PT. Taspen, maka Pemerintah Kabupaten Minahasa Selatan harus secara rutin melakukan koordinasi bersama dalam hal update data pegawai dan upgrade aplikasi apabila adanya pembaharuan yang berkaitan dengan penggunaan aplikasi tersebut.

2. Pemerintah Kabupaten Minahasa Selatan harus lebih teliti lagi dalam penyetoran dan pelaporan pajak penghasilan pasal 21 sehingga akan memperkecil kemungkinan terjadinya kesalahan dan terhindar dari sanksi administratif, karena hal tersebut merupakan salah satu bentuk pemborosan.

3. Pemerintah Kabupaten Minahasa Selatan juga harus lebih memperdalam mengenai pajak penghasilan pasal 21 dan lebih update mengenai peraturan-peraturan atau ketentuanketentuan perpajakan yang berlaku, mengingat peraturan perpajakan yang selalu mengalami perubahan. 


\section{DAFTAR PUSTAKA}

Wirawan, B. Ilyas. dan Richard Burton. 2013. Hukum Pajak, Teori Analisis, dan Perkembangannya, Edisi Enam. Salemba Empat, Jakarta.

Waluyo. 2010. Perpajakan Indonesia, Buku Satu, Edisi Sembilan. Salemba Empat, Jakarta.

Waluyo. 2011. Perpajakan Indonesia, Buku Satu, Edisi Sepuluh. Salemba Empat, Jakarta.

Waluyo. 2013. Perpajakan Indonesia, Buku Satu, Edisi Sebelas. Salemba Empat, Jakarta

Siti Resmi, 2011. Perpajakan Teori Dan Kasus, Edisi Enam, Buku Satu. Salemba Empat, Jakarta.

Kuncoro, Mudrajad 2003. Metode Riset untuk Bisnis dan Ekonomi. Erlangga, Jogjakarta.

http://www.sarjanaku.com/2012/07/pengertianpajakfungsipengelompokan.html Diakses pada tanggal 10 Oktober

http://www.pajak.go.id/content/seri-pph-pajak-penghasilan-pasal-21 Diakses pada tanggal 23 Oktober 2014

http://www.pajak.go.id/content/belajar-pajak Diakses pada tanggal 15 Oktober 2014

http://www.pajak.go.id/content/article/cara-penghitungan-pph-pasal-21-terbaru Diakses pada tanggal 20 Oktober 2014 